\title{
Percent of Tumor Cells
}

National Cancer Institute

\section{Source}

National Cancer Institute. Percent of Tumor Cells. NCI Thesaurus. Code C159484.

A quantitative measurement of the percent of tumor cells compared to the number of total cells present in a sample. 